\title{
Active Cycle Breathing Exercise on Post Tuberculosis Bronchiectasis
}

\author{
Ricky Gustian Halim, Siti Chandra Widjanantie, Selly C Anggoro
}

Department of Physical Medicine and Rehabilitation, Faculty of Medicine University of Indonesia/Dr. Cipto Mangunkusumo Hospital, Jakarta, Indonesia

Department of Physical Medicine and Rehabilitation, Persahabatan Hospital, Jakarta, Indonesia

\begin{abstract}
Introduction: Tuberculosis (TB) has remained as a major global health issue in Indonesia. Bronchiectasis frequently occurs in healing process, followed by excessive phlegm and low physical activity.

Methods: A case presentation of 49 years old female diagnosed as bronchiectasis post tuberculosis, difficulty to clear the phlegm, and inactive. Patient has undergone pulmonary rehabilitation by active cycle breathing exercise, 5 days a week, 30 minute/session, for 2 weeks.

Results: There was no dyspnea, patient easily remove phlegm, and can be more active, after cycle breathing exercise program.

Conclusion: Active cycle breathing exercise effective to relieve dyspnea, improving patient ability to clearance the phlegm, and increase physical activity.
\end{abstract}

Keywords: Bronchiectasis, active cycle breathing exercise, phlegm clearance, physical activity

\begin{abstract}
ABSTRAK
Pendahuluan: Tuberkulosis (TB) bertahan sebagai permasalahan kesehatan mayor secara global di Indonesia. Bronkiektasis biasanya terjadi pada proses penyembuhan, diikuti dengan dahak eksesif dan aktivitas fisik yang kurang.

Metode: Seorang wanita berumur 49 tahun didiagnosis sebagai bronkiektasis pasca tuberkulosis, kesulitan mengeluarkan dahak, dan tidak dapat melakukan aktivitas sedang. Pasien sudah menjalani rehabilitasi paru dengan latihan siklus penafasan aktif, 5 hari dalam seminggu, 30 menit/sesi, selama 2 minggu.

Hasil: Setelah 2 minggu tidak didapati sesak napas, pasien mudah mengeluarkan dahak, dan fisik menjadi lebih aktif.

Kesimpulan: Latihan siklus penafasan aktif efektif untuk memperbaiki sesak napas, meningkatkan kemampuan mengeluarkan dahak, dan meningkatkan aktivitas fisik.
\end{abstract}

Kata kunci: Bronkiektasis, Latihan Siklus Penafasan Aktif, Pengeluaran Dahak, Aktivitas Fisik. 
Correspondent Detail:

Ricky Gustian Halim

Department of Physical Medicine and Rehabilitation, Faculty of Medicine University of Indonesia/

Dr. Cipto Mangunkusumo Hospital, Jakarta, Indonesia

\section{INTRODUCTION}

Tuberculosis (TB) has remained as a major global health issue for almost two decades including in Indonesia. ${ }^{1}$ The number of TB prevalence and incidence has remained high. According to World Health Organization (WHO) in Global Tuberculosis Report 2018, Indonesia has a total of $360.565 \mathrm{~TB}$ cases that were notified by national authorities, while the estimated TB incidence was 1.020.000 and the annual incidence rate for 2017 was estimated at 319 per 100000 population per year for tuberculosis infection. ${ }^{2}$ Jakarta has 36.241 cases in 2018 which are one of the highest number of cases for tuberculosis infection in Indonesia. $^{3}$

Bronchiectasis frequently occurs in association with healed pulmonary tuberculosis that may be due to multiple factors, including traction from surrounding tissue fibrosis, caseous necrosis that makes its way into the bronchi, and elevated luminal pressure due to coughing. ${ }^{4,5}$ In Indonesia, there is no clear data about the etiology of bronchiectasis. In China, $\mathrm{Xu}$ et al. in 2013 found that the main causes of bronchiectasis were pulmonary TB $(31.17 \%)$, bacterial infection and pertussis. ${ }^{6}$ Similar with this report is several studies, a study by Dhar et al. identified post-infection (41\%) to be the primary cause for bronchiectasis with predominant etiology is post tuberculosis infection $(29.8 \%)$, other study by Palwatwichai et al. in Thailand found that the commonest etiology of bronchiectasis is post tuberculosis associated disease. ${ }^{7}$ prevalence and clinical features. Most bronchiectasis is reported to be idiopathic however post-infectious aetiologies dominate across Asia especially secondary to tuberculosis. Most focus to date has been on the study of airway bacteria, both as colonisers and causes of exacerbations. Modern molecular technologies including next generation sequencing (NGS

Bronchiectasis is a respiratory syndrome characterized by permanent and irreversible bronchial dilatation often accompanied by the formation of a chronic inflammatory exudate. The clinical presentation of bronchiectasis includes chronic productive cough, obstructive airways disease and recurrent respiratory infections. $^{8-10}$ Patients with bronchiectasis experience a reduction in exercise capacity and quality of life, fatigue and also episodic infective exacerbations that may lead to recurrent hospitalization. ${ }^{10,11}$ Patients with bronchiectasis usually receive pulmonary rehabilitation as management, especially in an outpatient context. ${ }^{12}$

Pulmonary rehabilitation (PR) is a nonpharmacological intervention that is designed for patients with chronic respiratory disease that includes exercise training, disease education and behavioral interventions to improve physical and psychological conditions 
of people with chronic respiratory disease and to promote the long term adherence to health-enhancing behaviors. For patients with bronchiectasis, pulmonary rehabilitation aims to improve exercise capacity, enhance disease management and improve quality of life. ${ }^{11}$ For the pulmonary rehabilitation programs are patients should be taught an airway clearance technique and take regular exercise. ${ }^{13}$ microbiology, physiotherapy, thoracic surgery, primary care, methodology and patients considered the most relevant clinical questions (for both clinicians and patients

\section{CASE PRESENTATION}

A 49 years old female patient diagnosed with post tuberculosis bronchiectasis from Pulmonary Department is consulted to Physical Medicine and Rehabilitation Department in Persahabatan Hospital. The patient complained about productive cough with white phlegm without blood streak especially in the morning and sometimes it was difficult to remove her phlegm. This condition already happened for about one month, but there was no episode of dyspnea except when she tried too hard to cough to remove her phlegm. She has no limitations in performing activities of daily living and can climb the stairs without breathlessness. The patient didn't has any episode of sleep disturbances caused by dyspnea. From her viewpoint, she is quite healthy and has only mild medical conditions. Her child also has the same viewpoint about her mother's medical conditions.

As the history of past illness, she complained of productive cough with blood streak phlegm, decreased bodyweight about $10 \mathrm{~kg}$ and diagnosed with lung tuberculosis in March 2018 and has already completed the medications in December 2018. According to the patient, she felt improvement after doing the treatments. There is no history of hospitalization related to her cough since she completed the medications. As for her family members, only her grandson that got the medical check-up to rule out the possibility of tuberculosis infection and her grandson was stated didn't have tuberculosis infection. The patient also has diabetes mellitus type 2 controlled with glimepiride and insulin injection once daily, hypertension controlled with amlodipine once daily and dyslipidemia controlled with simvastatin once daily.

The patient's education level is $5^{\text {th }}$ grade of elementary school with low-income level. She is unemployed, but she usually is helping her child in a stall in front of her house. Her child's education level is $6^{\text {th }}$ grade of elementary school, and the income for her family is from selling drinks and foods in her stall. Nowadays, she lives with her child and grandchild in 12-meter square rent house. The rent house is located in a crowded environment area with little sun exposure and have little ventilation. She usually drops off and picks up at the hospital by her child using a motorcycle. She stills can and has no difficulties in joining the activities in her neighborhood.

From her physical examination, the vital sign (blood pressure, heart rates, respiratory rates, oxygen saturation) is normal. The patient's body mass index is $26,4 \mathrm{~kg} / \mathrm{m}^{2}$ (Obesity Grade I according to Asia-Pacific Task Force). For the respiratory, there are no abnormal findings 
in inspection, palpation, and percussion of both sides of the chest, no additional lung sounds but there is limited chest expansion (3-3-4 cm). The peak flow rate is $370 \mathrm{~L} / \mathrm{min}$ and peak cough flow is $370 \mathrm{~L} / \mathrm{min}$. From the musculoskeletal, the muscles are normotrophy, normotones, limitation of range of motion from all extremities and normal muscle strength. The patient already done 6 minutes walking test and can achieved 408,5 meter with 4,4 METS.

For the management of this patient, she is programmed for pulmonary rehabilitation to be done for 6 to 8 weeks which consist of education, hospital-based rehabilitation and home-based rehabilitation programs. The education given to her is about the condition of her lungs, medical condition (bronchiectasis, obesity, diabetes mellitus type 2, hypertension and dyslipidemia), how important to control her medical conditions, plan for her rehabilitation programs, importance of compliance in doing the programs and the target of programs. Besides verbal education, she has also been demonstrated how to do the breathing and airway clearance techniques especially active cycle breathing techniques. For the hospitalbased rehabilitation programs, she is planned to do some programs such as breathing exercises, chest mobilization techniques, active cycle breathing techniques and targeted endurance exercise with a static cycle. For the homebased rehabilitation programs, she is planned to do breathing exercises, chest mobilization techniques, active cycle breathing techniques, proper posture and walking for specific durations and distances according to 6 minutes walking test result. She has been reminded via phone-calls to ensure she took the medications and done the home-based programs. After 2 weeks been doing the rehabilitation programs, the examination revealed there was no episode of dyspnea, she could remove her phlegm easily, and can be more active, after active cycle breathing program.

\section{DISCUSSION}

Regardless of the etiology, the cardinal symptoms of bronchiectasis are chronic cough and sputum production, almost all patients with bronchiectasis $(>90 \%)$ present with persistent cough. ${ }^{914}$ The chief complaint of the patient, in this case, is a productive cough without blood streak phlegm that occurs especially in the morning. The common presenting features of bronchiectasis include recurrent cough, recurrent lower respiratory tract infections and less frequently hemoptysis. Cole's vicious cycle hypothesis of infection and inflammation provides a bronchiectasis pathophysiology. The inflammation of airway in bronchiectasis eventually promotes mucus hypersecretion, lowering the threshold for cough, contribute to changes in bronchial wall geometry and promote mucus retention, hemoptysis and airway wall mechano-receptors. ${ }^{10}$

From her physical examinations, we found she has reduced chest expansion. The possible causes of reduction in chest expansion in the patient are bronchiectasis and obesity. A 6-minute walk test was done for evaluating her exercise capacity. The 6-minute walk test was recommended by the British Thoracic Society in guideline for bronchiectasis in adults for evaluation of exercise capacity pre and post pulmonary rehabilitation. 
European Respiratory Society in guidelines for the management of adult bronchiectasis recommended pulmonary rehabilitation as part ofmanagementforbronchiectasis whichbenefits are achieved in 6 to 8 weeks and maintained for between 3 to 6 months. ${ }^{13}$ microbiology, physiotherapy, thoracic surgery, primary care, methodology and patients considered the most relevant clinical questions (for both clinicians and patients Pulmonary rehabilitation (PR) is a non-pharmacological intervention designed for patients with chronic respiratory disease that includes exercise training, disease education, and behavioral interventions. ${ }^{11}$ As in this case's patient, she is programmed for pulmonary rehabilitation which consists of education, hospital-based rehabilitation, and homebased rehabilitation programs. She has been programmed for breathing exercises, chest mobilization techniques, active cycle breathing techniques, and targeted endurance exercise. In accordance with the American Thoracic Society/European Respiratory Society, the pulmonary rehabilitation individuals with chronic respiratory disease includes exercise training, education, exacerbation management, and physical activity. ${ }^{11}$

Communication and education are a must and important in this case's patient especially the understanding of her medical condition and the programs that were planned for her because from the viewpoint of her and her family, she only has a mild medical condition. She has multiple medical conditions from metabolic syndrome (obesity, diabetes mellitus type 2 , hypertension and dyslipidemia), pulmonary problems (bronchiectasis post tuberculosis).
Behar-Horenstein et al. in 2005 and The Joint Commission in 2010 concluded that patients who understand the information that is delivered by his/her healthcare providers can lead to enhanced satisfaction, better compliance with treatment instructions, improved outcomes, and decreased treatment times and costs. ${ }^{15}$ As a foundation of the pulmonary rehabilitation program, improving individuals' knowledge through the educational process of how to manage their disease is a must and important. The education of patients and their families should be a component of a pulmonary rehabilitation program. The patients that educated can become more skilled at collaborative self-management and have more compliance with their treatment plan which in turn may result in a reduction in hospital admissions. ${ }^{11}$ Some identified barriers included travel issues, competing commitments such as work and caring, fears that pulmonary rehabilitation would have little benefit or be detrimental to health, smoking history, degree of breathlessness, available social support and also the amount of information and enthusiasm of the referring physician. ${ }^{16}$ The educational component of pulmonary rehabilitation has gradually changed from a didactic approach to the promotion of adaptive behavior change, especially collaborative self-management. ${ }^{11}$ As in this patient, the education given to her is about her medical condition, the importance of the programs, the need for collaborating in the management. She has been demonstrated how to do the breathing techniques, chest mobilization techniques, active cycle breathing techniques, and proper posture. Besides that, she also been called via phonecall for educational purposes. 
As stated by the European Respiratory Society, patients with bronchiectasis that comply to pulmonary rehabilitation, show improvements in exercise capacity, cough symptoms and quality of life, and possibly a reduction in exacerbations. ${ }^{13}$ microbiology, physiotherapy, thoracic surgery, primary care, methodology and patients considered the most relevant clinical questions (for both clinicians and patients In this patient, she already feels easier to remove her phlegm after two weeks and no episode of dyspnea. She feels easier to remove her phlegm especially after doing active cycle breathing techniques. This condition is in accordance to Elsayed et al. study, the active cycle of breathing technique is an effective method for airway clearance and improving functional capacity in patients with bronchiectasis. ${ }^{17}$

\section{CONCLUSION}

Active cycle breathing exercise for 2 weeks, 5 days a week for 30 minute each session, can relieve dyspnea, improving phlegm mobilization, and increase physical activity in patient with post Tuberculosis Bronchiectasis.

\section{REFERENCES}

1. Fuady A, Pakasi TA, Mansyur M. The social determinants of knowledge and perception on pulmonary tuberculosis among females in Jakarta, Indonesia. Med J Indones. 2014;23(2):99-105.

2. GBD Tuberculosis Collaborators. Global, regional, and national burden of tuberculosis, 1990-2016: results from the Global Burden of Diseases, Injuries, and Risk Factors 2016 Study. Lancet Infect Dis. 2018;18(12):1329-1349. doi:10.1016/S1473-3099(18)30625-X

3. Kementerian Kesehatan Republik Indonesia. Data dan Informasi Profil Kesehatan Indonesia. Kurniawan R, Hardhana B, Yudianto, Siswanti T, editors. Jakarta: Pusat Data dan Informasi Kementerian Kesehatan; 2019. 1-207 p.

4. Ko JM, Kim KJ, Park SH, Park HJ. Bronchiectasis in active tuberculosis. Acta radiol. 2013;54(4):412-7.

5. Ravimohan S, Kornfeld H, Weissman D, Bisson GP. Tuberculosis and lung damage: from epidemiology to pathophysiology. Eur Respir Rev. 2018;27(147):170077.

6. Jin-Fu $\mathrm{X}$, Xiao-Bing $\mathrm{J}$, Hui-Ping $\mathrm{L}$, Hai-Wen L, Ke F, Li-Hong F, et al. Bronchiectasis caused by pulmonary tuberculosis: The epidemiology, clinical presentations and the differences from non-tuberculosis-caused bronchiectasis. Eur Respir J. 2013;42(Suppl 57):P2796.

7. Chandrasekaran R, Mac Aogáin M, Chalmers JD, Elborn SJ, Chotirmall SH. Geographic variation in the aetiology, epidemiology and microbiology of bronchiectasis. BMC Pulm Med. 2018;18(1):83.

8. Johnson C, Haworth C. Bronchiectasis. Medicine (Baltimore). 2016;44(5):31420.

9. Mac Aogáin M, Chotirmall SH. Bronchiectasis and cough: An old relationship in need of renewed 
attention. Pulm Pharmacol Ther. 2019;57(101812):1-7.

10. McCallion P, De Soyza A. Cough and bronchiectasis. Pulm Pharmacol Ther. 2017;47:77-83.

11. Spruit MA, Singh SJ, Garvey C, ZuWallack R, Nici L, Rochester C, et al. An Official American Thoracic Society/ European Respiratory Society Statement: Key Concepts and Advances in Pulmonary Rehabilitation. Am J Respir Crit Care Med. 2013;188(8):e13-64.

12. José A, Holland AE, Oliveira CS de, Selman JPR, Castro RAS de, Athanazio RA, et al. Does home-based pulmonary rehabilitation improve functional capacity, peripheral muscle strength and quality of life in patients with bronchiectasis compared to standard care? Brazilian J Phys Ther. 2017;21(6):473-80.

13. Polverino E, Goeminne PC, McDonnell MJ, Aliberti S, Marshall SE, Loebinger MR, et al. European Respiratory Society guidelines for the management of adult bronchiectasis. Eur Respir J. 2017;50(1700629):1-23.

14. Magge A, Ashraf S, Quittner AL, Metersky ML.. Quality of life in patients with bronchiectasis: a 2-year longitudinal study. Ann Trans1 Med. 2019;7(14):334. doi: 10.21037/atm.2019.06.62.

15. Marcus C. Strategies for improving the quality of verbal patient and family education: a review of the literature and creation of the EDUCATE model. Heal Psychol Behav Med. 2014;2(1):482-95.

16. Hayton C, Clark A, Olive S, Browne P, Galey P, Knights E, et al. Barriers to pulmonary rehabilitation: Characteristics that predict patient attendance and adherence. Respir Med. 2013;107(3):4017.

17. Elsayed SH, Kamal W, Abdel M, Fathy KA. Impact Of Active Cycle Of Breathing Technique On Functional Capacity In Patient With Bronchiectasis. Int $\mathrm{J}$ Ther Rehabil Res. 2015;4(5):287-93. 